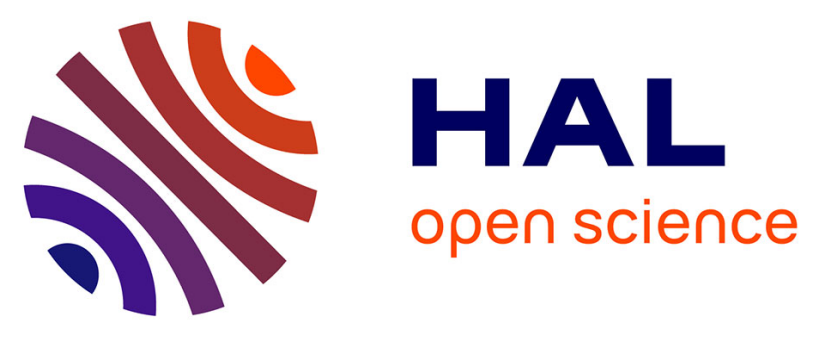

\title{
Chromatographic separation simulation of metal-chelating peptides from surface plasmon resonance binding parameters
}

Laurence Muhr, Steve Pontvianne, Katalin Selmeczi, Cédric Paris, Sandrine Boschi-Muller, Laetitia Canabady-Rochelle

\section{To cite this version:}

Laurence Muhr, Steve Pontvianne, Katalin Selmeczi, Cédric Paris, Sandrine Boschi-Muller, et al.. Chromatographic separation simulation of metal-chelating peptides from surface plasmon resonance binding parameters. Journal of Separation Science, 2020, 43 (11), pp.2031-2041. 10.1002/jssc.201900882 . hal-02938784

\section{HAL Id: hal-02938784 \\ https://hal.science/hal-02938784}

Submitted on 21 Sep 2020

HAL is a multi-disciplinary open access archive for the deposit and dissemination of scientific research documents, whether they are published or not. The documents may come from teaching and research institutions in France or abroad, or from public or private research centers.
L'archive ouverte pluridisciplinaire HAL, est destinée au dépôt et à la diffusion de documents scientifiques de niveau recherche, publiés ou non, émanant des établissements d'enseignement et de recherche français ou étrangers, des laboratoires publics ou privés. 
Chromatographic Separation Simulation of Metal-Chelating Peptides from Surface Plasmon Resonance Binding Parameters

Laurence MUHR ${ }^{1}$, Steve PONTVIANNE ${ }^{1}$, Katalin SELMECZI² ${ }^{2}$ Cédric PARIS³ , Sandrine BOSCHIMULLER $^{4}$ and Laetitia CANABADY-ROCHELLE ${ }^{1 *}$

${ }^{1}$ Université de Lorraine, Ecole Nationale Supérieure des Industries Chimiques, Laboratoire Réactions et Génie des Procédés (UMR CNRS-UL 7274), 1 rue Grandville, 54000 Nancy, France

2Université de Lorraine, Laboratoire Lorrain de Chimie Moléculaire UMR 7053 CNRS-UL, Boulevard des Aiguillettes, BP 70239, 54506 Vandoeuvre-lès-Nancy cedex, France

${ }^{3}$ Université de Lorraine, PASM platform, ENSAIA French engineering school, 2, avenue de la Forêt de Haye, 54000 Vandoeuvre-lès-Nancy, France

${ }^{4}$ Université de Lorraine, Laboratoire IMoPA, 54506 Vandoeuvre-lès-Nancy cedex, France

Running title: IMAC separation simulation of peptides from SPR binding parameters

(*) Author to whom the correspondence should be addressed:

E-mail: laetitia.canabady-rochelle@univ-lorraine.fr

Telephone number: $+33(0) 3.72 .74 .38 .86$.

Fax number: $+33(0) 3.83 .59 .58 .24$.

List of non-standard abbreviations:

IMAC: Immobilized Metal ion Affinity Chromatography

SPR: Surface Plasmon Resonance

MCP: Metal-Chelating Peptides

Key words: chelation, immobilized metal ion affinity chromatography, modelling, peptide, surface plasmon resonance.

Received: 29/08/2019; Revised: 25/01/2020; Accepted: 18/02/2020

This article has been accepted for publication and undergone full peer review but has not been through the copyediting, typesetting, pagination and proofreading process, which may lead to differences between this version and the Version of Record. Please cite this article as doi: $10.1002 /$ jssc. 201900882 .

This article is protected by copyright. All rights reserved. 
Abstract. Some metal-chelating peptides have antioxidant properties, with potential nutrition, health and cosmetics applications. This study aimed to simulate their separation on immobilized metal ion affinity chromatography from their affinity constant for immobilised metal ion determined in surface plasmon resonance, both technics being based on peptide-metal ion interactions. In our approach, first, the affinity constant of synthetic peptides was determined by surface plasmon resonance and used as input data to numerically simulate the chromatographic separation with a transport-dispersive model based on Langmuir adsorption isotherm. Then, chromatographic separation was applied on the same peptides to determine their retention time and compare this experimental $t_{R}$ with the simulated $t_{R}$ obtained from simulation from surface plasmon resonance data. For the investigated peptides, the relative values of $t_{R}$ were comparable. Hence, our study demonstrated the pertinence of such numerical simulation correlating immobilised metal ion affinity chromatography and surface plasmon resonance.

\section{Introduction}

Various industrial sectors (i.e. pharmacy, cosmetics, or food) have an increasing need of new biomolecules [1]. Peptides from plant and animal resources present a potential interest due to their bioactive properties, such as anti-hypertension [2, 3], anti-thrombosis [4], anti-carcinogenic effect [5], etc. Bioactive peptides can be obtained either by peptide synthesis, by their extraction from natural resources, or through protein hydrolysis. In this latter case, their use is often limited because of their presence in a complex mixture of peptides and also their low concentration in a peptide hydrolysate.

Antioxidant is a generic term that gathers various mechanisms including reducing capacity, radical scavenging activity and metal chelation activity. Transition metal ions can cause the production of radical species in organisms. Hence, upon metal chelation with a peptide, free radical production can be inhibited and oxidation phenomena delayed. According to the literature, some peptides with metal chelation properties would act as potential antioxidant according to their amino acid residues in their sequence. Indeed, the common structure of amino acid, $\mathrm{NH}_{2} \mathrm{CHRCOO}-$, contains $\mathrm{C}$-terminal carboxylate (COO-) and $\mathrm{N}$-terminal amino $\left(\mathrm{NH}_{2}\right)$ groups. These donor groups, with others from side chains such as the thiol 
group of cysteine, the imidazole group of histidine, the indole group of tryptophan or the carboxylate $\mathrm{COO}^{-}$of acid aspartic can bind to many metal ions $[6,7]$.

To this date, the separation of bioactive peptides inside a complex mixture is still studied empirically: peptides are separated into various fractions, each one being evaluated for their bioactivity up to isolate the peptide of interest and identify its sequence by mass spectrometry.

Various separation techniques take advantage of the interaction between an immobilised metal ion and a proteinous molecule (i.e. peptides, polypeptides or proteins) present in complex biological samples. Among them, immobilised metal ion affinity chromatography (IMAC) can separate proteins and peptides efficiently [8]. To separate proteins or peptides from complex mixture, IMAC has been studied for years [9]. Nevertheless, this technique presents some disadvantages i.e. the high cost of IMAC phase [8], a modest sensitivity, a throughput and limited flexibility, in addition to the waste of molecule of interest upon the washing up of the non-specific binding molecules [10]. Since chromatography is timeconsuming, a pre-screening system can help to determine the presence of metal-chelating peptides (MCP).

Some studies investigated the link between chromatography and Surface Plasmon Resonance (SPR) [11, 12]. This optical biosensor [13], which measures the change of refractive index, is related to the adsorption of the analyte initially circulating in solution onto the immobilized ligand. Such technology is comparable to Quartz Crystal Microbalance technology (QCM) to investigate the affinity and binding kinetics. Indeed, using a $\mathrm{Ni}^{2+}-\mathrm{NTA}$ chip, SPR could determine the affinity constant of peptide for $\mathrm{Ni}^{2+}$. SPR technology is similar to IMAC for a same complexing agent (NTA) and metal ion used. Hence, a methodology could consist in using the information provided by SPR to determine the operating parameters for IMAC separation process.

Vunnum et al. [14] successfully modelled IMAC using a non-linear multicomponent equilibrium in the case of proteins. Their simulation required input data such as the number of interaction sites of the protein when adsorbed on the stationary phase, a steric factor related to protein and the experimental determination of a linear equilibrium parameter for adsorption. In a different approach, the aim of this 
study was to simulate IMAC chromatographic process from SPR experimental data in order to guide the further peptide IMAC separation. To our knowledge, this approach is new and has never been investigated to date. The $\mathrm{Ni}^{2+}-\mathrm{IMAC}$ separation simulation from $\mathrm{Ni}^{2+}$-NTA-SPR data relies on the fact that both techniques are based on the same peptide-metal ion interaction mechanism. Indeed, we want to take advantage of SPR accuracy, technology which can determine dissociation constant $\left(K_{D}\right)$ from pM up to $\mathrm{mM}$, in order to enhance the efficiency of metal-chelating peptide enrichment by IMAC, knowing that experimental separation often requires large amount of resources and time.

To overcome this problem, the aim of this study was to simulate the IMAC separation of metal-chelating peptides from SPR data in order to make prediction of separation. Current theory and methods for surface interaction-based analysis/purification were developed from small synthetic molecules to significantly larger and complex biomolecules. Today, we can reveal the heterogeneity in assumed homogeneous interactions using sophisticated numerical tools like reported in the literature [15].

In our work, numerical simulations were tested. The program considered the affinity constant and the capacity deduced from SPR as a model input, the output corresponding to a retention time ( $\left.\mathbf{t}_{\mathbf{R}}\right)$ [16] related to a given imidazole concentration (IMC) required for MCP elution. In parallel, IMAC protocol was set up and applied to the same set of peptides. The simulated results were then compared with IMAC experimental data for validating the IMAC chromatographic modelling.

\section{Materials and Methods}

\subsection{Chemicals}

The studied peptides (i.e. HHH, HGH, HW, NCS, DAH, DTH, DSH, EAH, CAH, RTH, GNH) were purchased from GeneCust (Dudelange, Luxembourg; Supplementary information. Figure S1) and selected according to the literature $[17,18]$ (Supplementary information. Table S1). Their theoretical physical-chemical parameters were determined from Calpep free software (Supplementary information. Table S2). 
The NTA reagent kit, the BIAmaintenance Kit and nitriloacetic acid (NTA) sensor chip were purchased at GE Healthcare Bio-Sciences AB (Uppsala, Sweden).

The imidazole and hydrochloric acid solution were purchased from Sigma (Saint Louis, USA). The potassium phosphate monobasic $\left(\mathrm{KH}_{2} \mathrm{PO}_{4}\right)$ and tween 20 Bioxtra, were provided from Sigma Aldrich (Saint Louis, MO, USA). The sodium chloride $(\mathrm{NaCl})$ and di-sodium hydrogen phosphate dodecahydrate $\left(\mathrm{Na}_{2} \mathrm{HPO}_{4} \cdot 12 \mathrm{H}_{2} \mathrm{O}\right)$ were purchased from VWR Chemicals (Leuven, Belgium). The ethylenediamine tetraacetic acid disodium salt dihydrate $\left(\mathrm{EDTA}-\mathrm{Na}_{2} \cdot 2 \mathrm{H}_{2} \mathrm{O}\right)$ was purchased from Fluka Chemie (Buchs, Swiss). The sodium hydroxide (NaOH) $1 \mathrm{M}$ was purchased from Carlo ERBA (Val de Reuil, France). The sodium dodecyl sulfate (SDS) was purchased from Biosolve BV Chimie (Dieuze, France). The nickel(II) sulfate was purchased from Aldrich (Saint Louis, MO, USA). Ultrapure water (18.2 M $\Omega . \mathrm{cm}^{-1}$ ) was obtained using a Milli-Q System (Millipore, USA).

\subsection{Surface Plasmon Resonance}

\subsubsection{Buffer and peptide solution}

First, various buffers were prepared. The PBS 1X running buffer was prepared from a 10X PBS (67 mM $\mathrm{Na}_{2} \mathrm{HPO}_{4} .2 \mathrm{H}_{2} \mathrm{O}, 12.5 \mathrm{mM} \mathrm{KH} \mathrm{PO}_{4}, 150 \mathrm{mM} \mathrm{NaCl}, \mathrm{pH}$ 7.4). Upon dilution, the PBS $1 \mathrm{X}$ was $\mathrm{pH}-$ adjusted to 7.4 and tween $20(0.005 \%(\mathrm{v} / \mathrm{v}))$ added.

Several regeneration buffers were prepared as in Canabady-Rochelle et al. [19]: $500 \mathrm{mM}$ imidazole solution, a running buffer $(10 \mathrm{~mL}$ of PBS $1 \mathrm{X}, 0.005 \%$ tween $20, \mathrm{pH} 7.4$, containing $87 \mu \mathrm{L}$ EDTA at 350 $\mathrm{mM}$ ) and $0.5 \%$ SDS solution. Both imidazole and SDS solutions were prepared in ultrapure water. All SPR buffers were filtered onto a $0.2 \mu \mathrm{m}$-membrane filters (Whatman ${ }^{\mathrm{TM}}$, Buckinghamshire, UK). For viscous solutions (i.e. SDS), ultra-pure water was filtered before dissolving the chemicals. All peptides were dissolved in binding buffer PBS $1 \mathrm{X}$.

To plot SPR sorption isotherm, each peptide was studied at various concentrations ranging from 0 to 100 $\mathrm{mM}$. Over $50 \mathrm{mM}$, the $\mathrm{pH}$ of peptide solution was adjusted to $\mathrm{pH} 7.4$ when necessary, either with concentrated $\mathrm{NaOH}(10 \mathrm{~N})$ or $\mathrm{HCl}(37 \% \mathrm{v} / \mathrm{v})$. 


\subsubsection{Surface Plasmon Resonance experiments}

The SPR experiments were led similarly as in Canabady-Rochelle et al. [19] and reported briefly. The binding affinity of peptides and imidazole to $\mathrm{Ni}^{2+}$ was analysed by SPR at $25^{\circ} \mathrm{C}$ using a Biacore $\mathrm{X} 100$ instrument (GE Healthcare, Uppsala, Sweden) equipped with NTA sensor chips. All binding experiments were performed at a flow rate of $20 \mu \mathrm{L} \cdot \mathrm{min}^{-1}$. A 1-min injection of $\mathrm{Ni}^{2+}$ onto the NTA chip using a $\mathrm{NiCl}_{2}$ solution (500 mM, Biacore kit) was followed with a 1-min stabilization. The NTA flow channel uncharged in $\mathrm{Ni}^{2+}$ was used as reference channel. Then, the peptide sample was injected on both channels for 270 s followed by 270 s undisturbed dissociation time. Between each studied concentration, a regeneration procedure was performed as in Canabady-Rochelle et al. [19]. Four buffer blanks before and one at the end of the experiment were used as references during data processing.

The SPR sensorgramms were processed with BIAevaluate software to obtain isotherms expressed in Resonance Unit (RU, corrected by the offset value) as a function of the peptide concentration $\mathrm{C}(\mathrm{M})$. Considering the maximal response $\left(R_{\max }, R U\right)$, the dissociation constants $\left(K_{\mathrm{D}}, \mathrm{M}\right)$ were determined at equilibrium by fitting the experimental data with the 1:1 binding model. This former model follows the Equation 1.

$R=\frac{R_{\max } C}{K_{D}+C}$

\subsection{Immobilised Metal ion Affinity Chromatography numerical simulation}

\subsubsection{Langmuir adsorption theory}

In IMAC chromatography and for modelling purposes, knowledge of the equilibrium isotherm between the stationary phase and the liquid phase is essential. The original Langmuir adsorption isotherm describes a single layer adsorption. This former isotherm has a convex (upwards) curvature, between the linear part and the maximum surface coverage. For such a so-called Type I isotherm, the corresponding overloaded elution profile has a sharp front and a diffusive rear as previously described [20]. It tends to linearity at very low solute concentrations (low surface coverage) and towards an asymptotic value $q_{\max }$ 
for high concentrations (whole surface covered with solute). In chromatography, the general Langmuir equation is presented in Equation 2.

$q=\frac{q_{\max } K_{A} C}{1+K_{A} C}$

with $q_{\max }$, the maximal capacity $\left(\mathrm{g} / \mathrm{L}_{\text {stationary phase }}\right), K_{A}$, the affinity constant $(\mathrm{in} \mathrm{L} / \mathrm{g}$ ) and $\mathrm{C}$, the solute concentration in mobile phase $(\mathrm{g} / \mathrm{L})$.

For using Equation 2 during IMAC simulation, binding parameters $\left(K_{A}\right.$ and $\left.R_{\max }\right)$ measured in SPR must be first converted.

To discuss $K_{A}$ value transposition from SPR to IMAC, Equation 2 can be considered. For low peptide concentration in liquid phase, the isotherm slope is given by the $q_{\max } K_{A}$ factor, whose physical meaning is linked to the affinity of the peptide for the fixation sites. This affinity can reasonably be assumed independent of the geometry differences induced by a plane ship (SPR) or a spherical particle (IMAC).

As far as $\mathrm{C}$ value in Equation 2 is expressed in mass concentration $(\mathrm{g} / \mathrm{L})$, the affinity constant must be converted in L/g from the SPR value given in $\mathrm{M}^{-1}$, as described in Equation 3.

$K_{A, I M A C}=\frac{K_{A, S P R}}{M W}=\frac{1}{K_{D, S P R} \square M W}(\mathbf{3})$

where MW is the peptide molecular weight expressed in $\mathrm{g} / \mathrm{mol}$ and $K_{\mathrm{A}}$, SPR $\left(\mathrm{M}^{-1}\right)$, the inverse of the dissociation constant $\left(K_{D}, \mathrm{M}\right)$ measured in SPR.

By analogy to IMAC, the maximal SPR response $R_{\max }$ is reached when all the accessible ligand-binding sites are occupied by the analyte. Considering this and the work of Vunnum et al. [14], the amount of sites potentially occupied by a peptide depends on its multi-pointed adsorption and its steric hindrance effects. According to SPR chip specification, the binding of $1 \mathrm{ng} / \mathrm{mm}^{2}$ of protein to the sensor surface leads approximately to a response of $1000 \mathrm{RU}$. Since the matrix is about $100 \mathrm{~nm}$ thick, this represents a protein concentration within the matrix of $10 \mathrm{mg} / \mathrm{mL}$ [21]. Considering the specification given by Biacore and the works of Merwe (2018) [21], a concentration of $1 \mathrm{~g} / \mathrm{L}$ corresponds to $100 \mathrm{RU}$. Besides, the unit of 
$\mathrm{q}_{\text {max }, S P R}$ is given in $\mathrm{g} / \mathrm{L}$. Therefore, for SPR sensor chip, the $q_{\max }, S P R(\mathrm{~g} / \mathrm{L})$ was calculated according to

\section{Equation 4:}

$q_{\max , S P R}=\frac{R_{\max }}{100}$

where $q_{\max , S P R}$ is the liquid phase concentration at the NTA sensor chip interface $(\mathrm{g} / \mathrm{L})$ and $\mathrm{R}_{\max }$ the maximal resonance determined in SPR (Resonance Unit, R.U.).

Besides, for the building of our model and for a true transposition between SPR and IMAC, the $R_{\text {max }}$ must also be converted into a capacity value $\left(q_{\max }\right)$ for simulation. In chromatography, the capacity $\left(q_{\max }\right)$ is the quantity of species retained for a given mass or volume of stationary phase (e.g. g/L stationary phase). To transpose a liquid phase concentration in the vicinity of an interface in SPR $\left(q_{\max }, s P R\right)$ to a concentration in a solid phase in IMAC $\left(q_{\max }, I M A C\right)$, the accessible area of the stationary phase particle present in a given volume must be determined in IMAC. For a porous stationary phase in IMAC, the Ni ${ }^{2+}{ }_{-}$NTA grafted area accessible to peptides depends on porosity.

In spite of this difficulty, it can reasonably be assumed that the ratio $q_{\max }$ IMAC over $q_{\max }$, SPR does not change significantly for the various peptides. This ratio depends on the ratio area over volume of the stationary phase. Using $q_{\max }$, SPR value for IMAC simulation should therefore enable to compare peptides behaviours. Hence, a unique notation $q_{\max }$ will be used.

Finally, for better simulation, the competitive effect must also be taken into account especially when imidazole is used for elution in IMAC. For competitive adsorption of several components, the Langmuir adsorption must be adapted; in this latter case, $q_{i}$ is expressed using Equation $\mathbf{5}$

$q_{i}=\frac{q_{\max , i} K_{A, i} C_{i}}{1+\sum_{j=1, n} K_{A, j} C_{j}}$

Where $q_{\max , i}$ and $K_{A, i}$ are the parameters determined in mono-constituent conditions in Equation 2. 
2.3.2. Transport dispersive model simulation for immobilised metal ion affinity chromatography

The numerical simulation used pdepe solver (Matlab 2012b) to predict the retention time in IMAC. The program relies on a transport-dispersive model with Langmuir adsorption isotherm at low solute concentration. This model describes the mass transfer inside the column, assuming isothermal adsorption, radial homogeneity and lumped coefficients for axial dispersion and mass transfer resistances [20]. Drawing an analogy between a plug-flow reactor and the chromatographic column, it comprises a mass balance (Equation 6) and a kinetic equation for the stationary phase adsorption (Equation 7):

$\frac{\partial C_{i}}{\partial t}+\frac{1-\varepsilon_{T}}{\varepsilon_{T}} \frac{\partial q_{i}}{\partial t}+\frac{u}{\varepsilon_{T}} \frac{\partial C_{i}}{\partial z}=D_{L} \frac{\partial^{2} C_{i}}{\partial z^{2}} \forall i=1,2, \ldots, N_{c}$ and $z \in(0, L)$

$\frac{\partial q_{i}}{\partial t}=k_{m}\left(q_{i}^{*}-q_{i}\right)$

where $t$ is the time coordinate, $₹$ the axial coordinate, $\varepsilon_{T}$ the total porosity, $u$ the superficial velocity, $D_{L}$ the apparent axial dispersion coefficient, $N_{c}$ the number of components in the system, $L$ the column length, $k_{m}$ the lumped mass transfer coefficient, and $q^{*}$ the solute concentration in the stationary phase at equilibrium as defined by the adsorption equilibrium isotherm.

The apparent axial dispersion coefficient, $D_{L}$, is defined by an empirical correlation with $N p$, the theoretical plate number (Equation 8) as described in Guiochon et al. [22].

$D_{L}=\frac{u L}{2 N p}$

The number of theoretical plates can be determined experimentally from the chromatogram of an unretained small molecule by measuring the peak width at half maximum peak height.

The parameters used for simulation are presented in Table 1.

\subsection{Immobilized Metal ion Affinity Chromatography}

IMAC used a high-performance liquid chromatography (HPLC) system (Shimadzu, Japan) at room temperature and a flow rate of $1 \mathrm{~mL} \cdot \mathrm{min}^{-1}$. The HiFliQ column $(25 \mathrm{~mm} \times 7 \mathrm{~mm}$ i.d., $1 \mathrm{~mL}$ bed volume; 
Generon, UK) was prepacked with NTA resins. The parameters of HiFlick $\mathrm{Ni}^{2+}{ }^{2} \mathrm{NTA}$ FPLC column are presented in Supplementary information (Table S3). The column stored in ethanol was first washed with $0.25 \mathrm{M} \mathrm{NaCl}$ aqueous solution after connection to the HPLC. The agarose adsorbent phase was loaded with nickel ions until saturation by passing $10 \mathrm{mM}$ nickel sulfate solution in water through the column.

All peptide solutions were first prepared at $10 \mathrm{mM}$ in PBS $1 \mathbf{X}$ as those used in SPR (section 2.2.1). Before IMAC injection, they were diluted in PBS $1 \mathrm{X}$ to a final concentration of $2 \mathrm{mM}$. The PBS $1 \mathrm{X}$ was also employed as the binding buffer. The IMAC operating conditions used are presented in Table 1.

The separation process was done twice on a blank, i.e. $50 \mu \mathrm{L}$ of the binding buffer and then on peptide sample. After this step, the column was stripped and regenerated.

For IMAC, $50 \mu \mathrm{L}$ sample was injected after equilibrating the column by 5 column bed volume (BV, i.e. $1 \mathrm{~mL}$ ) of binding buffer. Afterward, 10-15 BV of the binding buffer was percolated through the column until a stable baseline was reached in the column out stream. Strong binding impurities were then eluted with a continuously increasing gradient of imidazole $(0-100 \mathrm{mM})$ in the same binding buffer for $30 \mathrm{~min}$. Finally, the column was washed with $0.25 \mathrm{M} \mathrm{NaCl}$ aqueous solution, $0.5 \mathrm{M} \mathrm{NaOH}$ in water and again $0.25 \mathrm{M} \mathrm{NaCl}$ aqueous solution, 10-15 $\mathrm{BV}$ each time. After each run, the resins were stripped and regenerated using sequentially $10 \mathrm{BV}$ of aqueous solutions: $100 \mathrm{mM}$ EDTA, $0.5 \mathrm{mM} \mathrm{NaOH}$ and then 10 $\mathrm{mM} \mathrm{NiSO}_{4}$, with ultrapure water before and after each solution. During chromatography, the absorbance was monitored at $232 \mathrm{~nm}$, corresponding to the peptide bond absorption [23]. The absorbance of the second blank was used for baseline subtraction.

\section{Results and Discussion}

\subsection{Peptide-metal ion interaction characterization}

\subsubsection{Theoretical physical-chemical and structural parameters of peptides}

The theoretical structures of studied peptides were plotted using Chemdraw free software (Figure S1). According to Sigel, peptide-metal ion chelation is favoured by the existence of anchors such as histidine 
in the peptide sequence [24]. Strong interactions are also expected when coordinating groups like hydroxyl(-OH), amine(- $\left.\mathrm{NH}_{2}\right)$, or carboxylate(-COO-) are presented in the side chain of the peptide.

Besides, physical-chemical properties of peptides were estimated according to PepCalc (Supplementary information. Table S2). They were further used to interpret the experimental chromatographic results. At $\mathrm{pH} 7.4$, negatively charged peptides are able to interact with positively charged metal ion $\mathrm{Ni}^{2+}$. Some peptides presented a negative charge of -0.9 (i.e. DMH, DAH, DTH, DSH, and EAH). According to Table S2, most of the investigated peptides possess an iso-electric point lower than 7.4, except $\mathrm{HHH}$, RTH, GNH, HGH and HW. Hence, these peptides are negatively charged under operating condition $(\mathrm{pH}$ 7.4) and their interaction with positively charged $\mathrm{Ni}^{2+}$ may be favoured.

According to Sigel and Martin [24], the chelate effect between peptide and metal ion is favoured with the presence of anchor present inside a peptide sequence such as histidine (i.e. HGH, HHH, DAH etc.). Besides, we expect a favoured interaction between peptide and metal ion when coordinating groups such as hydroxyl $(\mathrm{OH})$, amine $\left(\mathrm{NH}_{2}\right)$ or carboxylate are present in the side chain of a given peptide.

\subsubsection{Surface Plasmon Resonance sensorgramms and determination of binding parameters}

In SPR, peptides were studied over a range of concentrations, injected to react with the $\mathrm{Ni}^{2+}$ on the NTA$\mathrm{Ni}^{2+}$ chip. As example, the off-set-corrected sensorgramms obtained on NCS, HGH and HW peptides are given in Figure 1. Whole sensorgramms of all the investigated peptides are presented in supplementary data (Figure S2). When a given peptide presents an affinity with $\mathrm{Ni}^{2+}$ and its concentration is increased, the $\mathrm{Ni}^{2+}$ is saturated with peptides, corresponding to a plateau value (i.e. no more metal ions available for peptides in excess). In the range of concentration studied, all the investigated peptides (i.e. HHH, HGH, HW, NCS, DAH, DTH, DSH, EAH, CAH, RTH, and GNH) showed saturation.

From these sensorgramms, all the binding constants $\left(\mathrm{R}_{\max }, K_{D}\right.$ and $\left.K_{A}\right)$ were determined according to the 1:1 binding model fit (Equation 1), the $\mathrm{R}_{\max }$ being corrected by the off-set value of the corresponding isotherm (Table 2). 
The higher the $K_{A}$ value or the lower the $K_{D}$ value, the better the peptide affinity with metal ion. Hereafter, the $K_{A}$ is used to describe the affinity of peptides for immobilized $\mathrm{Ni}^{2+}$.

The $K_{A}$ value of $\mathrm{HHH}$ was of $1.44 \times 10^{4} \mathrm{M}^{-1}$. In 2009, Knecht et al. [25] found a $K_{A}$ value for $\mathrm{HHH}$ of 2 $\times 10^{5} \mathrm{M}^{-1}$, similar to our results considering our experimental conditions. We used Phosphate buffer with salt instead of HEPES with salt and EDTA in their experiments. Generally, other parameters of the method were similar. When considering Table 2, the affinity of peptides for $\mathrm{Ni}^{2+}$ evolves in the following rank:

\section{$\mathrm{HHH}>\mathrm{HW}>\mathrm{HGH}>\mathrm{NCS}>\mathrm{DTH}>\mathrm{CAH}>\mathrm{DAH}>\mathrm{DSH}>\mathrm{GNH}>\mathrm{EAH}>\mathrm{RTH}$.}

Generally, the Histidine-containing peptides present a noticeable affinity with metal ions, with $K_{A}$ varying from $1.61 \times 10^{2} \mathrm{M}^{-1}$ to $1.44 \times 10^{4} \mathrm{M}^{-1}$ for those containing either one or two His residues.

The $K_{A}$ values for $\mathrm{HHH}, \mathrm{HGH}$ and $\mathrm{HW}$ are comprised within $10^{3}-10^{4} \mathrm{M}^{-1}$ and are respectively 10 or 100 times higher than those of the others peptides $\left(\sim 10^{2} \mathrm{M}^{-1}\right)$. Hence, except for HW, peptides sequences containing two His residues present a higher affinity with $\mathrm{Ni}^{2+}$ as compared with peptides containing a single or no His residue.

The investigated peptides present either the His residue in the N-terminal part (i.e. HW, HHH, HGH), or in the C-terminus (i.e. RTH, DTH, GGH etc.). The first group presents a higher affinity with $\mathrm{Ni}^{2+}$ than the second one. In agreement with Liler [26], the metal ion chelation is stronger when substitution occurs on the amide nitrogen bound rather than through the substitution of hydrogen on the amide oxygen.

Hence, His residue seems important for peptide adsorption onto the immobilized $\mathrm{Ni}^{2+}$. These results agree with the study of Porath et al. [17] concerning the histidine- metal chelation capacity. 


\subsection{Immobilised Metal ion Affinity Chromatography metal-chelating}

\section{peptide elution}

\subsubsection{IMAC numerical simulation}

The SPR adapted parameters used for the simulations (i.e. $K_{A}(\mathrm{~g} / \mathrm{L})$ and $\left.q_{\max }(\mathrm{g} / \mathrm{L})\right)$ and according to our developed model, the simulated retention times obtained are presented in Table 2.

For the majority of investigated peptides (i.e. EAH, DSH, NCS, RTH, DTH, DAH, CAH, and GNH), the simulated retention time evolved form $0.54 \mathrm{~min}$ up to $0.78 \mathrm{~min}$. For peptides with higher binding affinity parameters in SPR (HGH, HW and $\mathrm{HHH})$, the simulated retention time was respectively of 4.18 $\min , 10.02 \mathrm{~min}$ and $10.34 \mathrm{~min}$.

\subsubsection{Experimental chromatography}

The Figure 2 presents the experimental chromatograms obtained for an elution carried out in the absence of imidazole for peptides NCS, HGH and HW taken as examples (Figure S3 in supplementary data for whole chromatograms). Whatever the peptide studied, a peak is observed at about 1.2 min. This

value corresponds to the time required for a non-retained species to go through the tubes and the column interstitial volume, until reaching the detector. This species may be an impurity, present in the various peptides investigated.

The time required to go through the tubes and the detector $\left(t_{m}, \mathrm{~min}\right)$ is therefore given by Equation 9.

$t_{m}(\min )=1.2-t_{0}(\min )(\mathbf{9})$

with $t_{0}(\mathrm{~min})$, the time required to go through column interstitial volume.

The former $\mathrm{t}_{0}$ value can be calculated using Equation 10.

$t_{0}=\frac{\varepsilon \mathrm{V}}{\mathrm{Q}}$

Where: 
- $\varepsilon$ is the porosity of the column $(\varepsilon=0.48)$,

- $\quad \mathrm{V}$ is the volume of the column $(\mathrm{V}=1 \mathrm{~mL})$

- and $\mathrm{Q}$ the flow rate $(\mathrm{Q}=1 \mathrm{~mL} / \mathrm{min})$.

According to our experimental conditions, $t_{0}$ is determined to be equal to $0.48 \mathrm{~min}$ and the

$t_{m}$ value can be calculated as equal to $0.72 \mathrm{~min}$. Hence, each experimental retention time value ( $\mathrm{t}_{\mathrm{R}}$, min) must be corrected by the former calculated $t_{m}$ value in order to evaluate the retention time in the column solely.

The experimental retention times, corrected or not by the $t_{m}$ are gathered in Table 2 . Note that for DTH peptide, the chromatogram presents several peaks and the choice of the appropriate peak is uncertain. Besides, the 3 most retained peptides (i.e. HGH, HW and $\mathrm{HHH}$ ) in experimental IMAC are those presenting indeed the highest affinity constant determined in SPR.

\subsubsection{Comparison between simulation and experimentation}

The Figure 2 compares the experimental and the simulated chromatograms for peptides HGH, NCS and HW solely. These compounds were chosen since their simulated retention times were in good agreement with the experimental one in the absence of imidazole (Table 2). As previously mentioned, the experimental set up includes tubes and detector whereas simulations take only into account the retention in the column. The correction factor, $t_{m}$ value of $0.72 \mathrm{~min}$, must therefore be considered to compare experimental and simulated chromatograms, which are in quite good agreement.

Figure 3, presenting the experimental retention time measured in IMAC as a function of the simulated retention time using our developed model, allows the comparison of the retention time obtained either by experiment or simulation for all the studied peptides. It can be observed that for the peptide species weakly bound (i.e. EAH, DSH, RTH, DTH, DAH, CAH, GNH), the simulation slightly underestimates the retention times whereas for the most retained peptides species (i.e. HW and $\mathrm{HHH}$ ), this one is overestimated. Despite these gaps, the trend is correct since the peptides are distributed close the bisectrix. 
Hence, from data obtained in SPR, we can simulate with accuracy the peptide retention in a IMAC column.

In our study, the elution chromatography was simulated at low peptide concentration. Hence, the retention time depends mainly on the slope $\left(K_{A} q_{\max }\right)$ of the isotherm at the origin corresponding to the linear part of the isotherm while the $\mathrm{q}_{\max }$ asymptotic value has almost no significant impact on this retention time. Therefore, the correct trend between simulation and experimental retention time tends to validate the product $q_{\max } K_{A}$ but further work must be carried out to estimate each value, which must be transposed for IMAC separately. Indeed, each value of $K_{A}$ and $\mathrm{q}_{\max }$ taken independently have an impact on the shape of the Langmuir isotherm. These former values affect the shape of chromatograms obtained, notably on the diffusive rear. We can observe that the rear of chromatogram is more diffusive in the case of simulation contrarily to those observed in the case of chromatographic experiments. This observation justifies the work planned in perspectives to estimate each value of $K_{A}$ and $\mathrm{q}_{\max }$ independently.

\subsection{Application of simulation: imidazole concentration effect on the peptide retention time}

In order to optimize the separation time and to evaluate the effect of the imidazole concentration on the retention time, some simulations can be done. In this latter case, the Langmuir competitive sorption isotherm described by Equation 5 was used with $K_{A}(\mathrm{~L} / \mathrm{g})$ and $q_{\max }(\mathrm{g} / \mathrm{L})$ parameters determined for imidazole in SPR and adapted for IMAC simulation given in Table 2.

As example, the Figure 4 presents the evolution of the simulated retention time of $\mathrm{HW}$ as a function of the imidazole concentration in the case of isocratic elution. Figure 4 was obtained from 22 simulations launched at fixed imidazole concentration, each simulation giving a simulated retention time.

Similarly, some simulations were carried out to optimise a gradient in the case of multi-component separations. The Figure 5 compares the separation of HW, HGH and NCS in the absence (panel A) and in the presence (panel B) of imidazole gradient varying from 0 to $100 \mathrm{mM}$, for $30 \mathrm{~min}$. It can be observed that the use of an imidazole gradient enables to decrease the separation time from 15 min down to 10 
min, while keeping a good separation. These simulations are presented in order to illustrate some examples of applications of the simulation tool we developed, even if we do not have the corresponding experimental measurements to confront experience and simulations.

\section{Conclusion and Perspectives}

The aim of this work was to simulate peptide elution in $\mathrm{Ni}^{2+}-$ IMAC from SPR data in order to predict chromatographic separation. While taking into account the advantages of biosensors over IMAC chromatography in terms of peptide quantity and solvent volumes used, experimental cost could be largely reduced before launching time-consuming separation steps.

An appropriate simulation would enable to predict the peptides' retention time in IMAC and the effect of the imidazole concentration upon elution. In this work, the IMAC behaviour of 11 small-sized peptides (mainly di and tri-peptides) was simulated by a MatLab ${ }^{\circledR}$ program from their affinity constant and capacity determined in SPR and then confronted to experimental data obtained in IMAC chromatography.

A transport-dispersive model, along with Langmuir adsorption isotherm, was chosen for numerical simulation of IMAC. The comparison of simulated IMAC retention times with the experimental ones proved that the modelling was correct, which tends to validate the transposition of the product $\mathrm{K}_{\mathrm{A}} \mathrm{q}_{\max }$ from SPR to IMAC. Simulation developed in this work can provide both a general idea on the time of retention in IMAC and the effect of imidazole concentration on elution behaviour. Hence, the order of peptide affinity determined in SPR gives a trend for the peptide elution in IMAC, where the di and tripeptides containing either two histidine residues (i.e. $\mathrm{HHH}$ and $\mathrm{HGH}$ ) or a $\mathrm{N}$-term histidine (i.e. $\mathrm{HW}$ ) can be detected as having affinity with $\mathrm{Ni}(\mathrm{II})$, at the same time, they can be adsorbed to the $\mathrm{Ni}$ (II) on the IMAC column. To confirm this trend, the same methodology should be applied to a larger bank of peptide ( 200 peptides).

The perspectives of this work focus on the estimation of both $K_{A}$ and $q_{\max }$ value itself for IMAC simulations (and not only the $K_{A} q_{\max }$ product), that could be applied to higher concentration ranges in peptide. The knowledge of these data will enable to simulate chromatographic modes such as frontal chromatography for preparative purposes. 
Methodology aiming at predicting $\mathrm{q}_{\max , \mathrm{IMAC}}$ from $\mathrm{q}_{\max }$, SPR must be developed. For that purpose, $\mathrm{q}_{\max , \mathrm{IMAC}}$ should be experimentally determined for imidazole and for several peptides using frontal chromatography, which requires a significant amount of pure peptides. Calculation of the ratio $\frac{q_{\max , S P R}}{q_{\max , I M A C}}$ for imidazole and peptides should allow to check whether this ratio presents a significant variation or not whatever the peptide sequence. If this ratio presents small variations, the methodology will rely on the determination of this ratio for imidazole only, avoiding the need of a significant amount of expensive pure peptides.

Besides, the values of $K_{A}$ and $\mathrm{q}_{\max }$ will be further adjusted and validated by comparison of the rear of the chromatograms (simulated versus experimental).

Finally, the approach set up in our work for simple sites should be deepen for more complex systems as initiated by Forssen et al. [15].

\section{Acknowledgments}

The authors would like to thank Jingwen TAN, Jingiao REN, Hugo MARTINS-LIBONE. Besides, they acknowledge support of the "Laboratoire Réactions et Génie des Procédés" by the "Impact Biomolecules" project of the "Lorraine Université d'Excellence"(Investissements d'avenir - ANR project number 15-004).

\section{Conflict of interest: none}

\section{$5 \quad$ References}

[1] Valeur E., Guéret S.M., Adihou H., Gopalakrishnan R., Lemurell M., Waldmann H., Grossmann T.N., Plowright A.T., New modalities for challenging target in drug discovery. Angew. Chem. Int. Ed. 2017, 56, 10294-10323.

[2] Marczak E.D., Usui H., Fujita H., Yang Y., Yokoo M., Lipkowski A.W., Yoshikawa M., New antihypertensive peptides isolated from rapeseed. Peptides, 2003, 24, 791-98. 
[3] Pihlanto-Leppälä A., Bioactive peptides derived from bovine whey proteins: opioid and aceinhibitory peptides. Trends Food Sci. Technol., 2000, ,11, 347-56.

[4] Ariyoshi Y., Angiotensin-converting enzyme inhibitors derived from food proteins. Trends Food Sci. Technol., 1993, 4, 139-144.

[5] Messina M., Messina V., Increasing use of soyfoods and their potential role in cancer prevention. J. American Diet. Assoc., 1991, 91, 836-40.

[6] Wong J.W., Albright R.L., Wang N.-H., Immobilized metal ion affinity chromatography (IMAC) chemistry and bioseparation applications. Sep. Purif. Methods, 1991, 20: 49-106.

[7] Porath J., IMAC-Immobilized metal ion affinity based chromatography., TrAC Trends Anal. Chem., 1988, 7, 254-59.

[8] Alhazmi H.A., Nachbar M., Albishri H.M., Abd El-Hady D., Redweik S., El Deeb S. Watzig H., A comprehensive platform to investigate protein-metal ion interactions by affinity capillary electrophoresis. J. Pharm. Biomed. Anal. 2015, 107, 311-317.

[9] Helfferich F., Ligand exchange: a novel separation technique. Nature, 1961, 189, 1001-02.

[10] Weinberger S.R, Morris T.S., Pawlak M. Recent trends in protein biochip technology, Pharmacogenomics, 2000, 1, 395-416.

[11] Hernández V.A., Samuelsson J., Forssén P., Fornstedt T. Enhanced interpretation of adsorption data generated by liquid chromatography and by modern biosensors. $J$. Chromato A., 2013, 1317, 22-31.

[12] Arnell R., Ferrza N., and Fornstedt T. Analytical Characterization of Chiral Drug-Protein Interactions: Comparison between the Optical Biosensor (Surface Plasmon Resonance) Assay and the HPLC Perturbation Method. Anal. Chem. 2006, 78, 1682-1689. 
[13] Jönsson U., Fägerstam, L., Löfas, S., Stenberg, E., Karlsson, R., Frostell, A., Markey, F. and Schindler, F., Introducing a biosensor based technology for real-time biospecific interaction analysis. In Ann. biol. clin., 1992, 19-26.

[14] Vunnum S., Gallant S.R., Kim Y.J., Cramer S.M., Immobilized metal affinity chromatography: Modeling of nonlinear multicomponent equilibrium. Chem. Eng. Sci., 1995, 50,11, 1785 1803.

[15] Forssén P., Multia E., Samuelsson J., Andersson M., Aastrup T., Altun S., Wallinder D., Wallbing L., Liangsupree T., Riekkola M.-L., and Fornstedt T. Reliable Strategy for Analysis of Complex Biosensor Data. Anal. Chem., 2018, 90, 5366-5374.

[16] Fornstedt T., Forssén P., Westerlund D. Basic HPLC Theory and Definitions:

Retention,Thermodynamics, Selectivity, Zone Spreading, Kinetics, and Resolution, in: V. Pino, J.L. Anderson, A. Berthod, A.M. Stalcup (Eds.), Anal.Sep. Sci., Wiley-VCH Verlag GmbH \& Co. KGaA, Weinheim, Germany, 2015: pp. 124.http://doi.wiley.com/10.1002/9783527678129.assep001 (accessed January 23, 2017).

[17] Porath J., Carlsson J., Olsson I., Belfrage G., Metal chelate affinity chromatography, a new approach to protein fractionation. Nature, 1975 258: 598-599.

[18] Hemdan E.S., Porath J., Development of immobilized metal affinity chromatography: II. Interaction of amino acids with immobilized nickel iminodiacetate. J. Chromatogr. A, 1985, 323: 255-64.

[19] Canabady-Rochelle L., Selmeczi K., Collin S., Pacs A., Muhr L. and Boschi-Muller S. SPR Screening of Metal chelating Peptides for their Antioxidant Properties. Food Chem., 2018, $239,478-485$.

[20] Fornstedt T. Characterization of adsorption processes in analytical liquid-solid chromatography. J. of Chromatogr. A, 2010, 1217: 792-812. 
[21] Merwe P.A. 2018. Surface plasmon resonance. From biophysics: http://www.biophysics.bioc.cam.ac.uk/wp-content/uploads/2011/02/spr1.pdf

[22] Guiochon G., Felinger A., Shirazi, D.G., Katti A.M., Fundamentals of Preparative and Nonlinear Chromatography, 2nd Ed. San Diego: Academic Press imprint of Elsevier, Boston, MA, 2006.

[23] Schmid F.X., Biological Macromolecules: UV-visible Spectrophotometry, eLS. 2001.

[24] Sigel H., Martin R.B. Coordinating properties of the amide bond. Stability and structure of metal ion complexes of peptides and related ligands. Chem. Rev., 1982, 82: 385-426.

[25] Knecht S., Ricklin D., Eberle A.N., Ernst B., Oligohis-tags: Mechanisms of binding to $\mathrm{Ni}^{2+}{ }^{2+N T A}$ surfaces. J. Mol. Recognit., 2009, 22, 270-279.

[26] Liler M., Studies of nuclear magnetic resonance chemical shifts caused by protonation. Part I. Substituted acetamides and some N-methyl-and NN-dimethyl-derivatives. J. Chem. Soc. B: Phys. Org. 1969, 385-89. 
Figure 1. Sorption isotherms obtained for NCS, HGH and HW model peptides corrected by the offset.
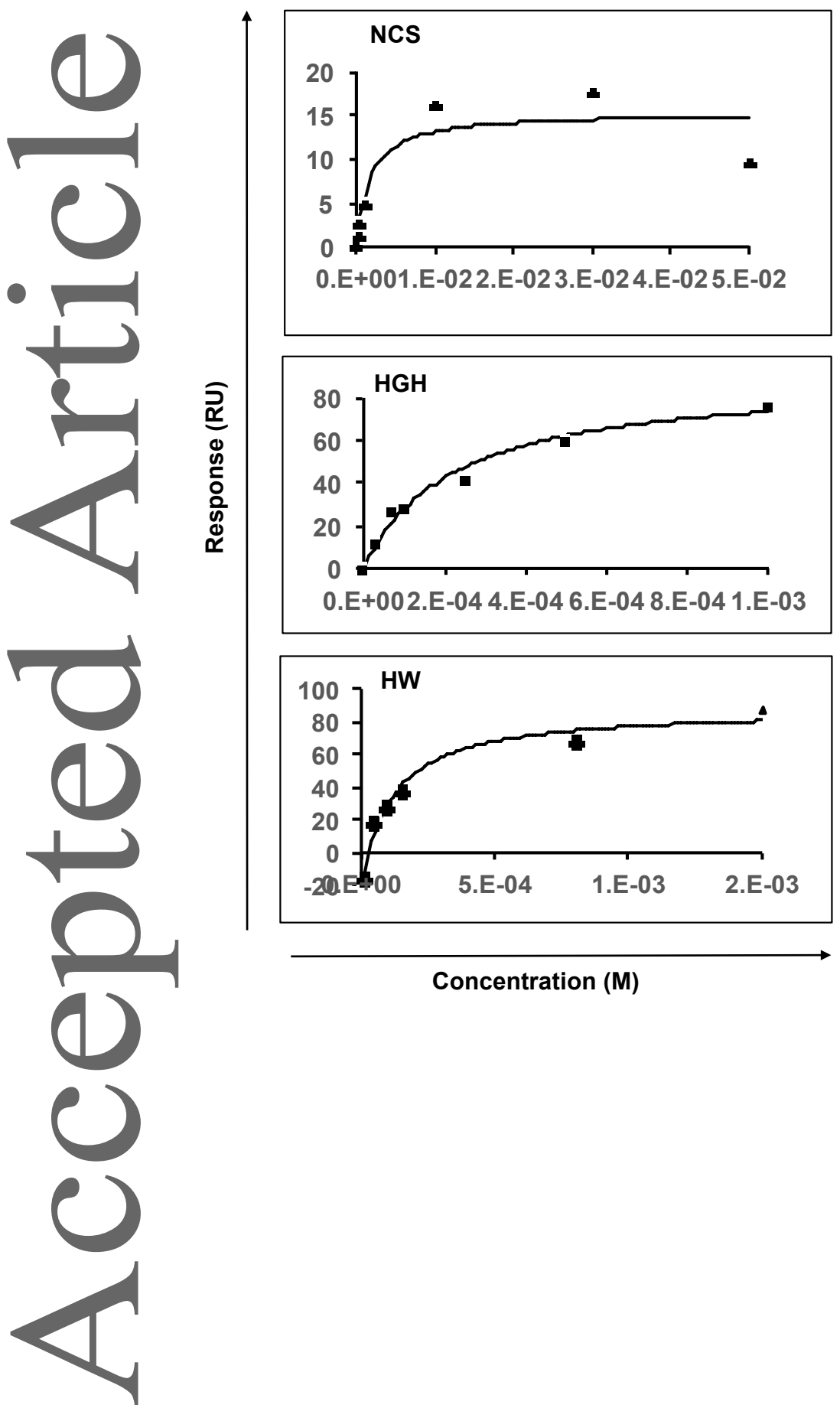
Figure 2. Comparison between experimental chromatograms obtained during elution without imidazole for some peptides (NCS, HGH, and HW) $(\lambda=232 \mathrm{~nm})$ and their simulated chromatograms. Panels (A),

(C) and (E): experimental chromatograms. Panels (B), (D) and (F): Simulated chromatograms.

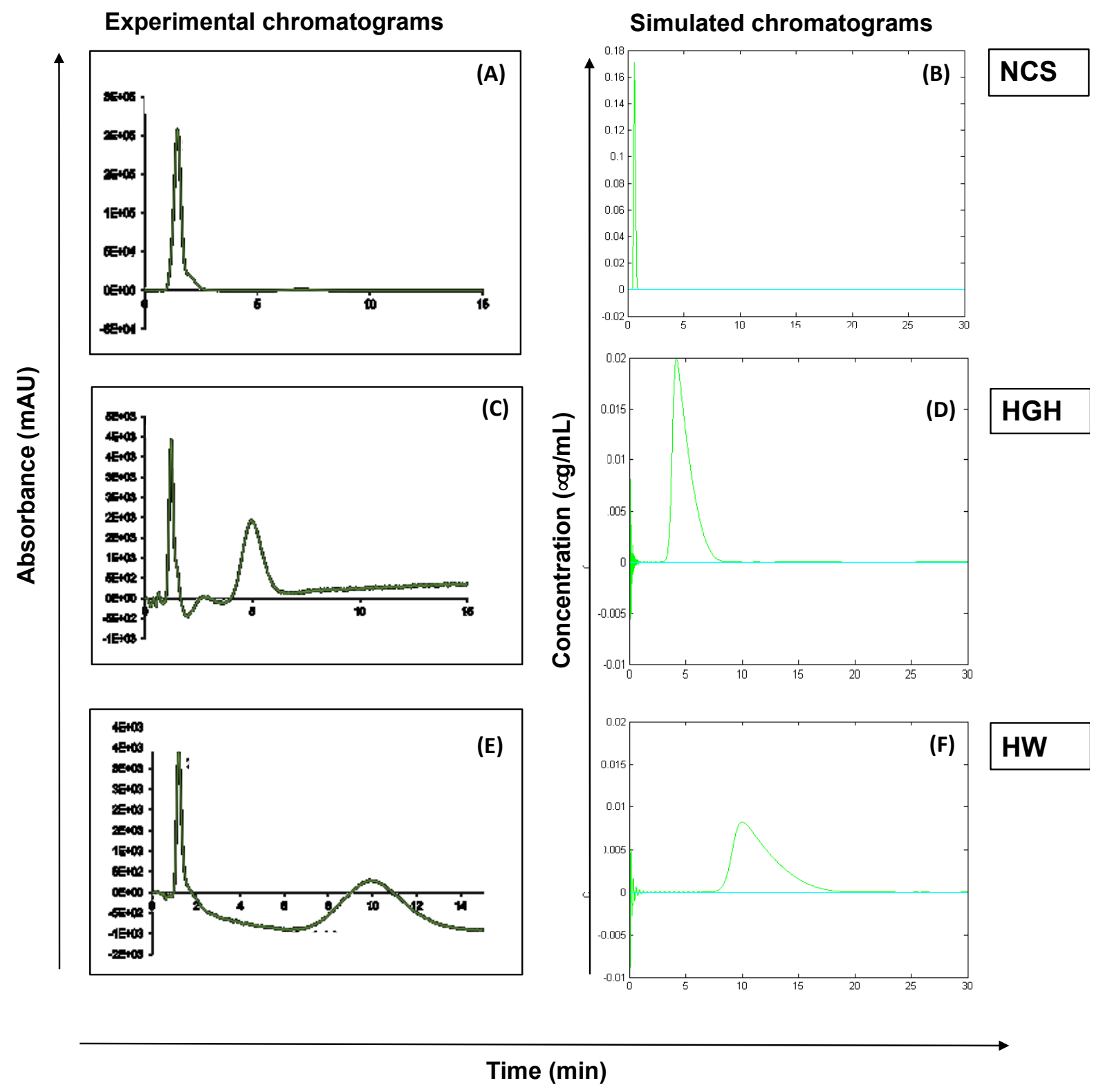


Figure 3. Comparison of experimental and simulated retention time in IMAC.

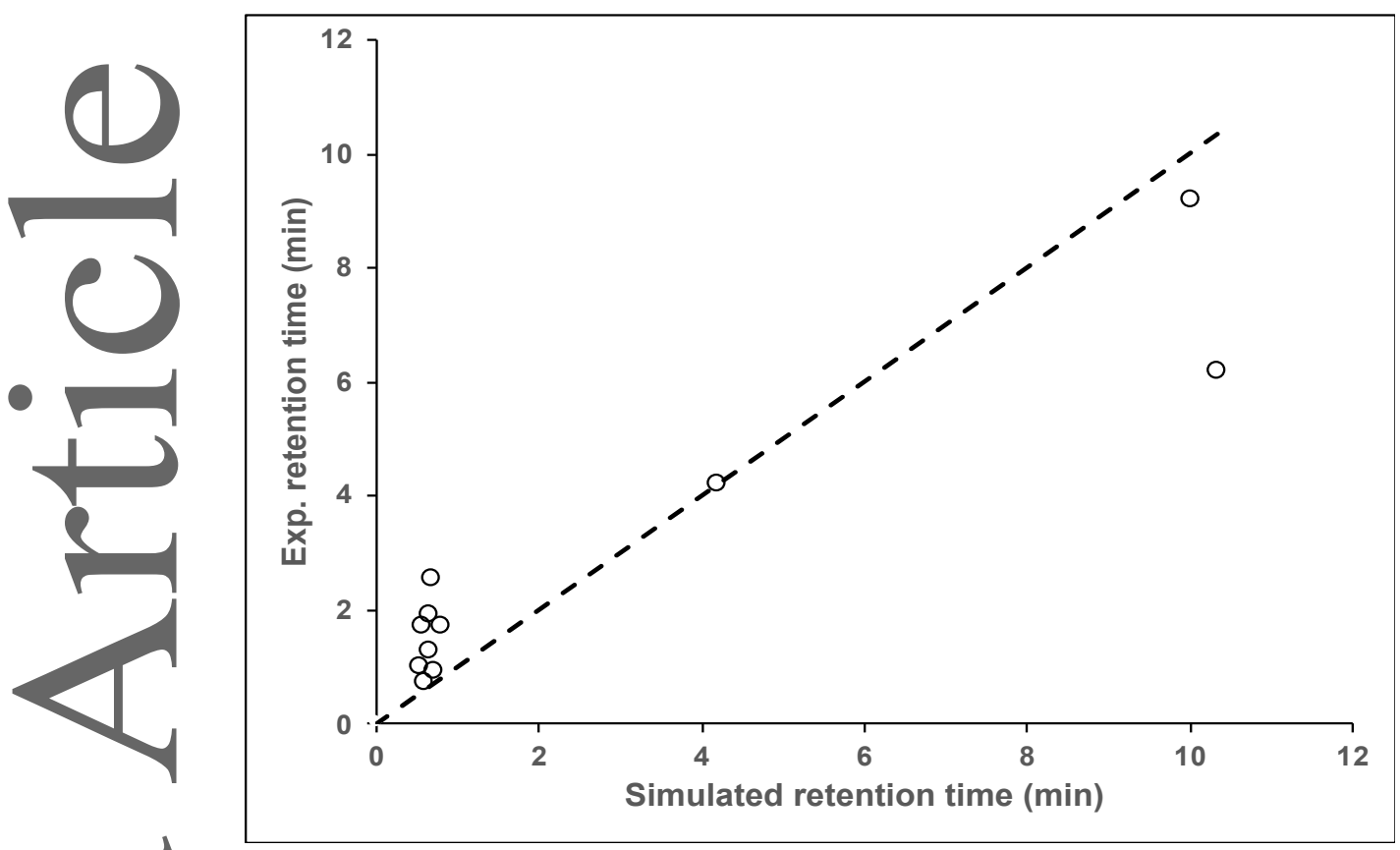

Figure 4. Evolution of the simulated retention time of HW as a function of the imidazole concentration for an elution carried out in isocratic mode.

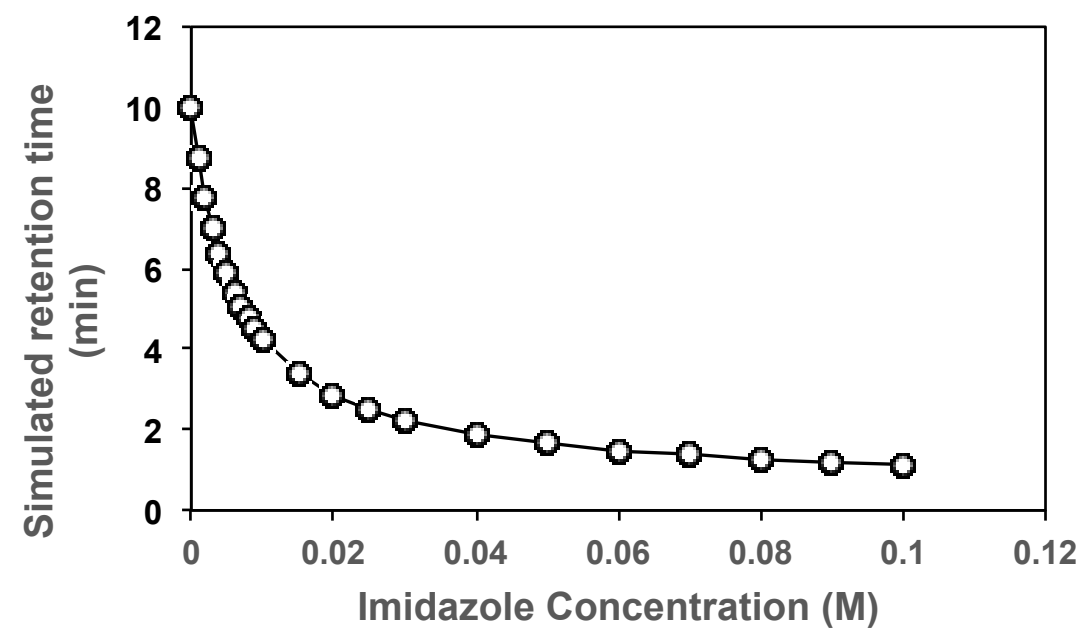


Figure 5. Simulation of the separation of HW, HGH and NCS without (A) and with (B) an imidazole gradient, varying from 0 to $100 \mathrm{mM}$ in 30 minutes.

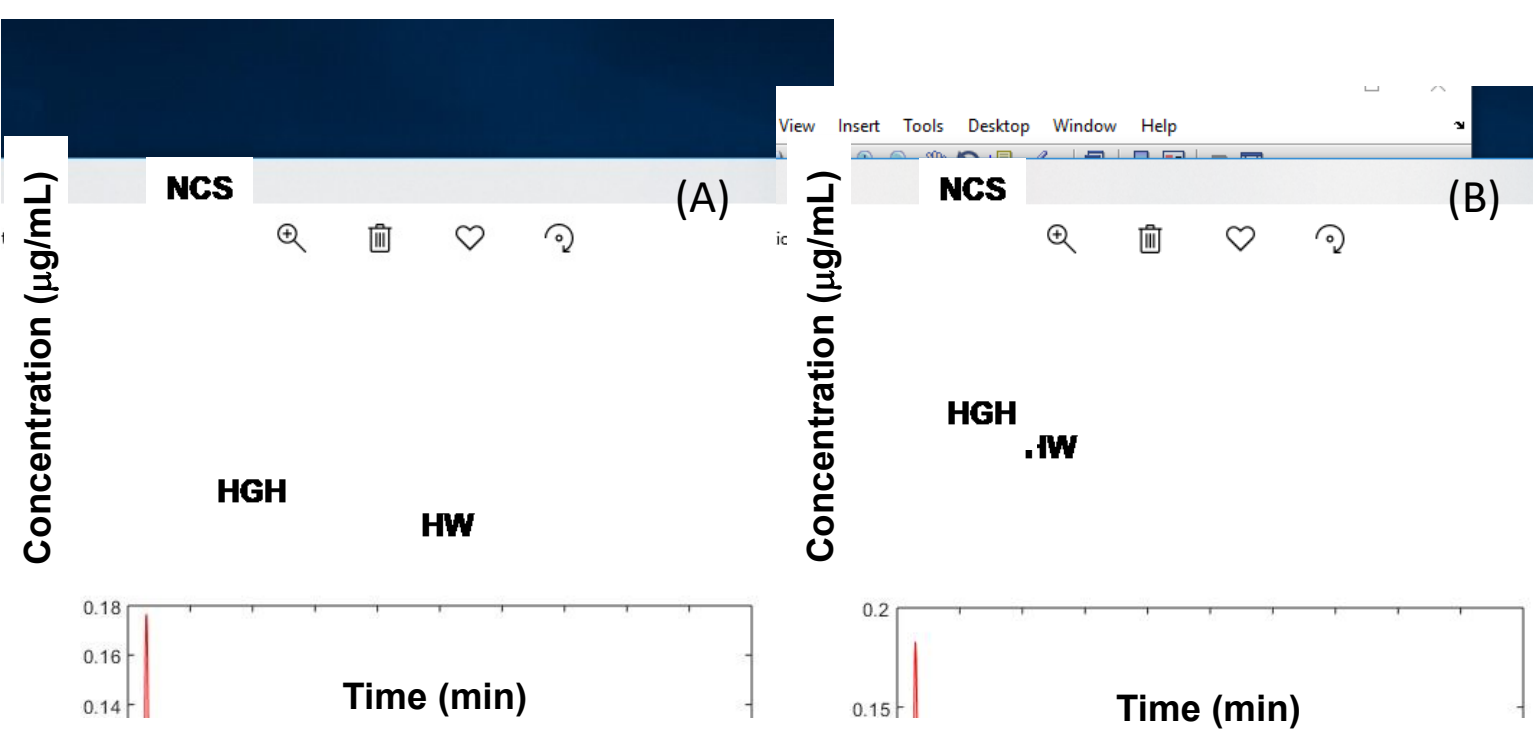


Table 1. Parameters used for Matlab ${ }^{\circledR}$ numerical simulation and IMAC experiments.

\begin{tabular}{lll}
\hline Parameters & Value & Unit
\end{tabular}

\section{Matlab numerical simulation}

Column diameter

Column height

$\mathrm{cm}$

Flow rate

Simulation time

$\min$

Gradient of imidazole

Total porosity*

0.48

Lumped mass transfer coefficient $\left(\mathrm{k}_{\mathrm{m}}\right)^{\text {* }}$

Apparent axial dispersion coefficient

$\left(D_{\mathrm{L}}\right)$ *

\section{IMAC experiments}

Binding buffer

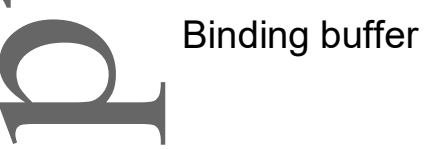

Elution buffer

Elution time

Sample volume

Peptide sample concentration

Column regeneration frequency
PBS 1X: $6.7 \mathrm{mM} \mathrm{Na}_{2} \mathrm{HPO}_{4}, 1.25$ $\mathrm{mM} \mathrm{KH}_{2} \mathrm{PO}_{4}$ and $15 \mathrm{mM} \mathrm{NaCl}, \mathrm{pH}$

Imidazole solution with linear concentration gradient from 0 to $100 \mathrm{mM}$

$\min$ 50

$\mu \mathrm{L}$

${ }^{*}$ Rough estimation 
Table 2. Simulated retention times obtained from SPR experimental data and experimental retention times obtained in IMAC.

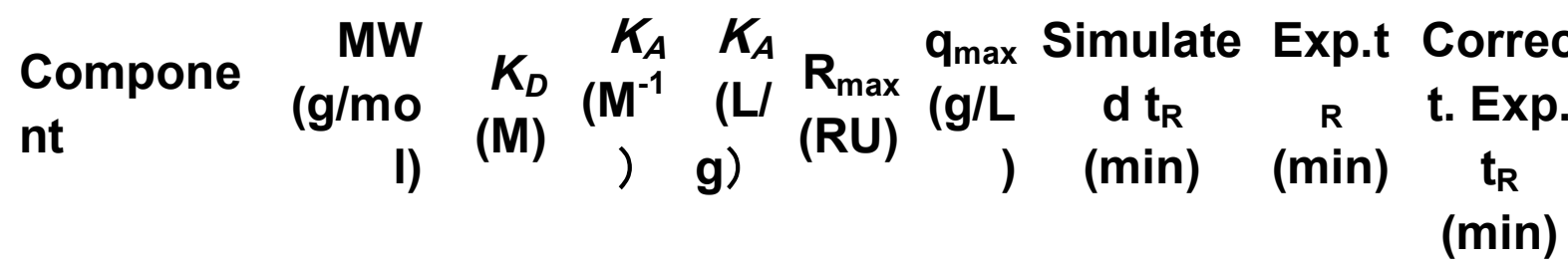

\begin{tabular}{|c|c|c|c|c|c|c|c|c|c|}
\hline Imidazole & 68.077 & $\begin{array}{l}6.24 \\
\text { E-03 }\end{array}$ & 160 & 2.35 & 41.35 & 0.41 & - & - & - \\
\hline $\mathrm{EAH}$ & 355.35 & $\begin{array}{l}5.92 \\
\text { E-03 }\end{array}$ & 169 & 0.48 & 28.54 & 0.29 & 0.54 & 1.71 & 0.99 \\
\hline DSH & 357.32 & $\begin{array}{r}5.59 \\
\text { E-03 }\end{array}$ & 179 & 0.50 & 39.90 & 0.40 & 0.56 & 2.44 & 1.72 \\
\hline NCS & 322.34 & $\begin{array}{l}2.07 \\
\text { E-03 }\end{array}$ & 483 & 1.50 & 23.59 & 0.24 & 0.60 & 1.46 & 0.74 \\
\hline RTH & 412.44 & $\begin{array}{l}6.21 \\
\text { E-03 }\end{array}$ & 161 & 0.39 & 95.34 & 0.95 & 0.64 & 1.99 & 1.27 \\
\hline DTH & 371.35 & $\begin{array}{l}2.70 \\
\text { E-03 }\end{array}$ & 370 & 1.00 & 41.20 & 0.41 & 0.64 & 2.64 & 1.92 \\
\hline DAH & 341.32 & $\begin{array}{r}3.50 \\
\text { E-03 }\end{array}$ & 286 & 0.84 & 58.76 & 0.59 & 0.68 & 3.27 & 2.55 \\
\hline $\mathrm{CAH}$ & 329.38 & $\begin{array}{l}2.70 \\
\text { E-03 }\end{array}$ & 370 & 1.12 & 51.81 & 0.52 & 0.70 & 1.64 & 0.92 \\
\hline GNH & 326.31 & $\begin{array}{r}5.71 \\
\text { E-03 }\end{array}$ & 175 & 0.54 & $\begin{array}{r}127.1 \\
0\end{array}$ & 1.27 & 0.78 & 2.43 & 1.71 \\
\hline $\mathrm{HGH}$ & 349.35 & $\begin{array}{l}2.32 \\
E-04\end{array}$ & 4310 & $\begin{array}{r}12.3 \\
4\end{array}$ & 93.70 & 0.94 & 4.18 & 4.94 & 4.22 \\
\hline HW & 341.36 & $\begin{array}{r}1.13 \\
\text { E-04 }\end{array}$ & 8850 & $\begin{array}{r}25.9 \\
3\end{array}$ & $\begin{array}{r}109.9 \\
0\end{array}$ & 1.10 & 10.02 & 9.91 & 9.19 \\
\hline $\mathrm{HHH}$ & 429.43 & $\begin{array}{r}6.94 \\
E-05\end{array}$ & $\begin{array}{r}1440 \\
0\end{array}$ & $\begin{array}{r}33.5 \\
3\end{array}$ & 99.78 & 1.00 & 10.34 & 6.89 & 6.17 \\
\hline
\end{tabular}

